\title{
MICROPROPAGAÇÃO DA AMOREIRA-PRETA CV. BRAZOS
}

\section{MICROPROPAGATION OF BLACKBARRY CV. BRAZOS}

\author{
Carolina Smanhoto Schuchovski AUGUSTO \\ Orientador(a): Prof. Dr.Luiz Antonio BIASI \\ (Departamento: Fitotecnia e Fitossanitarismo)
}

\section{RESUMO}

A amoreira-preta (Rubus sp.) é uma espécie propagada vegetativamente, principalmente pela estaquia de ramos e raízes. No entanto, há muitos problemas fitossanitários decorrentes desta técnica. Este trabalho objetiva definir um protocolo eficiente para a micropropagação de amoreira-preta, oferecendo uma alternativa aos métodos de propagação tradicionalmente utilizados no Brasil. Utilizaram-se plantas matrizes da cultivar Brazos, mantidas em casa de vegetação. Realizou-se um experimento de assepsia de segmentos nodais, testando a imersão em hipoclorito de sódio $(0,5 \%)$ por $0,10,20$ e 30 minutos. Na fase de cultivo inicial testaram-se concentrações (0; 1 e 2 g.L-1 $)$ do antioxidante PVP K 25 com ápices meristemáticos. Na fase de multiplicação, testaram-se as citocininas BAP, cinetina, zeatina, 2iP e tidiazuron nas concentrações de 5 e $10 \mathrm{mM}$, mais a testemunha. Este experimento foi repetido por mais três subcultivos. Outro experimento na fase de multiplicação foi realizado testando-se os meios de cultura MS, MS/2, AND, QL e WPM. Este experimento foi repetido por mais dois subcultivos. Na fase seguinte realizou-se um experimento de enraizamento in vitro com ou sem imersão em solução $1 \mathrm{mM}$ de AIB. Outro experimento de enraizamento foi realizado em casa de vegetação com nebulização intermitente, com as plantas provenientes dos tratamentos do experimento de multiplicação com diferentes citocininas. Na fase final testou-se a influência da sacarose no meio de cultura de enraizamento na aclimatação em casa de vegetação em túnel plástico ou sob nebulização intermitente. Os resultados foram os seguintes. A contaminação dos explantes foi reduzida com a utilização de $\mathrm{NaOCl}$ em todos os tempos de imersão. $\mathrm{O}$ PVP, nas duas concentrações testadas, reduziu a oxidação. No experimento de multiplicação com citocininas, o tidiazuron não se mostrou viável devido à má formação dos brotos e crescimento exagerado de calos. As mais altas taxas de multiplicação foram obtidas com BAP, nas duas concentrações testadas, obtendo-se 4,4; 6,1; 7,9 e 2,6 brotos por micro-estaca para a concentração de 5 mM e 4,3; 4,7; 4,8 e 2,1 para $10 \mathrm{mM}$, na seqüência dos quatro subcultivos. No experimento de multiplicação com meios de cultura, nos três subcultivos houve uma tendência de maior taxa de multiplicação com o meio MS, apresentando 3,9; 4,3 e 2,5 brotos por micro-estaca para a primeira, segunda e terceira repicagens. No experimento de enraizamento in vitro, obteve-se mais de $95 \%$ de enraizamento nos dois tratamentos. No enraizamento ex vitro, as taxas de enraizamento e sobrevivência foram de $100 \%$. No experimento de aclimatação, em todos os tratamentos houve $100 \%$ de sobrevivência. Pode-se concluir que um protocolo eficiente para a micropropagação de amoreira-preta é a assepsia com imersão por 10 minutos em $\mathrm{NaOCl}$ a $0,5 \%$, com adição de $1 \mathrm{~g} \cdot \mathrm{L}^{-1}$ de PVP na fase inicial, multipliçação no meio MS com 5 mM de BAP e enraizamento in vitro sem AIB e sem a adição de sacarose ao meio de cultura, com posterior aclimatação em túnel plástico ou o enraizamento ex vitro e aclimatação em casa de vegetação com nebulização intermitente.

Palavras-chave: amora-preta, Rubus sp., micropropagação, cultura de tecidos, reguladores de crescimento.

\begin{abstract}
Blackberry (Rubus sp.) is a species vegetatively propagated, specially by root and herbaceous cuttings. However, there are many phytosanitary problems derived from these propagation methods. The aim of this work was to achieve an efficient blackberry micropropagation protocol, offering an alternative to the tradicional propagation methods used in Brazil. Mother plants from Brazos cultivar were kept into a greenhouse. Disinfestation experiments with nodal stems were done to test the imersion in a $0,5 \%$ solution of sodium hypochlorite for 0,10 , 20 and 30 minutes. In the establishment stage, several concentrations of the antioxidant PVP K $25\left(0,1\right.$ and 2 g. $\left.\mathrm{L}^{-1}\right)$ were tested in the meristem culture. In the multiplication stage, different cytokinins (BAP, kinetin, zeatin, 2iP and thidiazuron) were tested in two concentrations $(5$ and $10 \mathrm{mM}$ ) plus growth regulator free medium. This experiment was repeated for more three subcultures. Another experiment during the multiplication stage was done to test different culture media with the treatments as follows: MS, MS/2, AND, QL and WPM. This experiment was repeated for more two subcultures. In the following stage, an in vitro rooting experiment was done with or without imersion in a $1 \mathrm{mM}$ solution of indolbutiric acid. Another rooting experiment was done in a greenhouse with intermittent mist with the plants proceeding from the same treatments from the multiplication experiment with different cytokinins. In the final stage the influence of sucrose from the rooting media was tested in the acclimatization in greenhouse under plastic tunel or under intermittent mist. The results found were that the explant contamination was reduced with the use of $\mathrm{NaOCl}$ in all the imersion time. The PVP, in the two tested concentrations, reduced oxidation. In the multiplication experiment with cytokinins, thidiazuron was not viable because of the shoot malformation and great callus formation. The highest multiplication rates were obtained with BAP in the two tested concentrations, obtaining 4.4, 6.1, 7.9 and 2.6 shoots per explant in the $5 \mathrm{mM}$ concentration and 4.3, 4.7, 4.8 and 2.1 shoots per explant in the $10 \mathrm{mM}$ concentration, in the four subcultures. In the multiplication experiment with culture media, in the three subcultures, there was a tendency of higher multiplication in MS media, reaching 3.9, 4.3 and 2.5 shoots per explant in the first, second and third subculture. The percentage of rooting was higher than $95 \%$ in both treatments of in vitro rooting. For the ex vitro rooting experiment, the rooting and survival rates were $100 \%$. In the acclimatization experiment all the treatments showed $100 \%$ of survival. It can be concluded that an efficient protocol for blackberry micropropagation is: disinfestation for 10 minutes imersion in sodium hypochlorite $(0.5 \%)$, adding $1 \mathrm{~g} \cdot \mathrm{L}^{-1}$ of PVP in the initial stage, multiplication in MS media suplemented with BAP ( $\left.5 \mathrm{mM}\right)$ and in vitro rooting without indolbutiric acid and without sucrose in the culture media with acclimatization under plastic tunel or ex vitro rooting and acclimatization under intermittent mist in a greenhouse.
\end{abstract}

Key-words: blackberry, Rubus sp., micropropagation, tissue culture, growth regulators. 